\title{
Argumento: literatura e cultura nos anos 70*
}

Argumento: literature and culture in the $70 \mathrm{~s}$

\author{
Débora Cota \\ Universidade Federal da Integração Latino-americana - Foz do Iguaçu - Paraná - Brasil
}

$\diamond$

Resumo: Estudo de um periódico brasileiro dos anos 70, censurado pela ditadura militar, que procura traçar o projeto cultural da publicação através da análise de dados e textos, bem como da época de sua circulação. Sua importância tanto se relaciona à reunião de nomes notáveis da crítica latino-americana entre colaboradores e organizadores como ao fato de trazer um quadro bastante expressivo de sua época. Em outubro de 2014 completa quarenta anos do fim deste periódico que não só registrou em suas páginas um cenário da vida cultural dos anos 70 brasileira, com cenas importantes sobre a América hispânica, como também definiu e demarcou discursos constituidores da história literária do continente.

Palavras-chave: Periodismo; Cultura; Anos 70

\begin{abstract}
Study of a Brazilian journal published in the 70s and censored by the military dictatorship. I seek to trace the publication cultural project through the analysis of its related context, data and texts. The journal's importance is due to the presence of many notable Latin American literary critics among its publishers and collaborators and to the fact that it depicts a very expressive frame from this historical period. October 2014 marks the 40 years anniversary of its end. The journal recorded on its pages the scenario of the Brazilian and the HispanoAmerican cultural life in the 70 s as well as it had a role in defining constitutional discourses that constitute part of the literature history of the continent.
\end{abstract}

Keywords: Periodism; Culture; 70s

O periodismo literário e cultural, seja de cunho acadêmico, seja de grupos autônomos, tem um importante papel de divulgação tanto da produção literária e cultural quanto das discussões em torno delas. Se por um lado é formador de opinião, munido de seu tempo, uma vez que privilegia a produção atualizada, torna-se comumente marca de sua época e registro de discursos constituidores da história de um período. O que segue é uma apresentação de um periódico que, no ano de 2014, completa 40 anos de encerramento. Foi o fim de um projeto que, em apenas 4 números, demonstrou contundência e clareza nas apostas que fazia não só para o Brasil mas para o continente latino-americano.

A revista Argumento, hoje, serve de fonte histórica a muitas pesquisas. Mas, a pertinência de trazê-la à tona nos dias atuais também se vincula a revisão da história do seu período de existência, posta em prática, sobretudo,

\footnotetext{
* Trata-se de artigo elaborado a partir da pesquisa de dissertação de mestrado da autora, defendido na Universidade Federal de Santa Catarina, em 2001
}

pelo aniversário de 50 anos do golpe militar no Brasil e a consequente instalação da Comissão Nacional da Verdade, que tem como missão investigar violações de direitos humanos, praticadas por agentes do Estado, no período circunscrito aos anos de 1946 a 1988, no Brasil. Além da Comissão oficial, várias outras Comissões da Verdade paralelas foram constituídas em todo país, espalhando as discussões sobre este conturbadíssimo período da história, do qual a revista é testemunho e produto.

Publicada pela editora Paz e Terra, a Argumento - revista mensal de cultura circulou no Brasil entre os meses de outubro de 1973 e fevereiro de 1974. Seu desaparecimento e efemeridade deveu-se a intervenção da polícia. A edição de número 3 foi parcialmente apreendida, enquanto a quarta estava no prelo (KUCINSKI, 1991, p. 276). Com expressiva tiragem - de 25.500 exemplares pulou para 45.500 no terceiro número -, pode-se afirmar que, no período, circulou ao lado de periódicos de pequeno e grande porte, como o jornal $O$ Estado de $S$. Paulo, o Jornal da Tarde, o Opinião, o Pasquim, a revista $V e j a$, a revista alternativa $E x$, dentre outros. 
O breve período de circulação é marcado pela continuidade do regime militar, com a troca de um general, Emílio Garrastazu Médici, por outro, Ernesto Geisel, e pela oposição do MDB, único partido de oposição legalizado. À época, o MDB denunciava a eleição indireta e lançava como "anticandidatos", em chapa única, Ulysses Guimarães e o então diretor de Argumento, Barbosa Lima Sobrinho. Cabe acrescentar que era também o momento de auge (em que se iniciava o declínio) do chamado "milagre brasileiro".

No decorrer deste e de outros acontecimentos, a revista se armava: na redação de textos que abordavam temas políticos, econômicos, sociais, literários, cinematográficos, teatrais, entre outros, temas que a configurava como uma revista cultural, e, ao mesmo tempo, na reunião de um grupo de intelectuais com bastante visibilidade nacional, vinculados, em sua maioria, a uma instituição comum, a Universidade de São Paulo. Muniu-se de um conjunto de intelectuais, que dava coerência a seu modo de resistir e que não só legitimava a publicação, mas demonstrava conhecimento e domínio de sua principal arma: a argumentação. Além de seu importante diretor, Barbosa Lima Sobrinho, formavam o Conselho Consultivo: Alceu Amoroso Lima, Érico Veríssimo, Hélio Jaguaribe, Florestan Fernandes, Paulo Duarte, Sérgio Buarque de Holanda, Simão Mathias, (Brasil), Anibal Pinto, Octavio Paz, Torcuato di Tella, (América Latina), Albert Hirschman, Brian Van Arkadie, Dudley Seers, (Europa e Estados Unidos). Já a Comissão de Redação trazia os nomes de Anatol Rosenfeld, Antonio Candido de Mello e Souza, Celso Furtado, Fernando Henrique Cardoso, Francisco Corrêa Weffort, Luciano Martins e Paulo Emilio Salles Gomes, além de Elifas Andreato que figura como diretor de arte.

Alguns membros do grupo da Comissão de Redação trabalhavam ou já haviam trabalhado juntos em outros periódicos: do jornal Opinião, em circulação desde 1972, encontravam-se em Argumento Celso Furtado, JeanClaude Bernardet e Fernando Henrique Cardoso como colaboradores e Elifas Andreatto como editor gráfico; da revista Clima (década de 40), os protagonistas Paulo Emilio Salles Gomes e Antonio Candido; da Revista Civilização Brasileira (década de 60), Francisco Weffort e Fernando Henrique Cardoso. Muitos destes ainda estavam ligados à mesma academia, Universidade de São Paulo, como professores ou como estudantes.

Em quatro números, a Argumento - revista mensal de cultura manteve-se com as mesmas dimensões e apresentou uma média de 155 páginas por edição. As capas, sempre com o mesmo formato, traziam, na parte superior e em letras de tamanho grande, o título do periódico e, logo abaixo, seu subtítulo, número, volume e preço. Abaixo destas informações, com exceção do quarto número, todas traziam um grande quadrado que tomava o resto do espaço da capa e era preenchido por um título, em destaque, de um ensaio publicado naquele número, uma ilustração em cores e os nomes de alguns dos colaboradores, com exceção do número 2, que, em vez de trazer os nomes dos colaboradores, apresentou os títulos de alguns dos ensaios publicados. A capa tinha como estratégia, portanto, chamar a atenção através dos nomes de autores que colaboravam naquela edição, dando prestígio à publicação. $\mathrm{O}$ ensaio destaque de cada número, junto aos nomes de colaboradores, indica o campo de atuação deste periódico.

Através dos sumários pode-se observar a distribuição dos textos na revista: primeiramente, um conjunto de ensaios, entrecortados em dois números (2 e 4 ) por uma entrevista e, em seguida, espaço para as resenhas. Os ensaios são, assim, encontrados em maior número na publicação, seguidos das resenhas, informes, entrevistas e depoimento. Dentre os assuntos mais recorrentes estão: literatura, cinema, teatro e artes plásticas. Mas, são recorrentes também ensaios sobre economia, política e sociologia.

Dentre os ensaios destaca-se a presença de alguns que tiveram grande repercussão na área literária: "Literatura e subdesenvolvimento", de Antonio Candido"; "Cinema: trajetória no subdesenvolvimento", de Paulo Emilio Salles Gomes2; "Criando o romance brasileiro", de Roberto Schwarz 3 ; e, "Estética e ideologia: o modernismo em 1930”, de João Luiz Lafetá4.

\section{Contra fato, há argumento}

Argumentar tem, no âmbito da retórica, a função de "captar o assentimento", "induzir à persuasão ou à convicção", ser razão que dá fé de algo duvidoso, convencer. Assim, o termo 'argumento', do latim argumentum, quer dizer: prova, motivo, indício, demonstração ou razão que

\footnotetext{
Segundo Antonio Candido, em A educação pela noite e outros ensaios, este ensaio foi publicado, em tradução francesa de Claude Fell, na revista Cahiers d'Histoire Mondiale, Unesco, 4, 1970, e em espanhol, na obra coletiva a que se destinava, América Latina en su literatura (Coordenação e introdução de César Fernández Moreno), México, Unesco/Siglo Veintiuno, 1972, editada em português pela Editora Perspectiva (São Paulo, 1979). Em português, foi publicado pela primeira vez na revista Argumento, São Paulo, n. 1, out. 1973 e, posteriormente, como capítulo do livro A educação pela noite e outros ensaios, São Paulo: Ed. Ática, 1989.

2 Publicado em forma de livro de bolso, pela editora Paz e Terra, na "coleção leitura" em 1996.

3 Também foi publicado como capítulo do livro, do mesmo autor, intitulado: Ao vencedor as batatas: forma literária e processo social nos inícios do romance brasileiro, 1981 (2. ed.), sob o título: "A importação do romance e suas contradições em Alencar".

4 Trata-se de um capítulo da Dissertação de Mestrado do autor, orientada por Antonio Candido e defendida na USP em maio de 1973, ou seja no mesmo ano de lançamento de Argumento. Encontra-se também publicado como capítulo do livro 1930: a crítica e o modernismo, (1974), sob o título: "Modernismo: projeto estético e ideológico".
} 
carrega consigo a função persuasiva ou de convencimento. $\mathrm{Na}$ lógica ou na matemática, a palavra pode ser encontrada com o significado de "tema ou objeto de um discurso qualquer, aquilo em torno de que o discurso versa ou pode versar" (ABBAGNANO, 2007, p. 79). Também pode implicar raciocínio, desenvolvimento de um pensamento que leva a uma consequência ou dedução.

Antes de outras considerações, convém lembrar que argumentação é linguagem usada com o intuito de convencer, persuadir e dar provas de algo incerto. Os argumentos seriam, portanto, as proposições utilizadas com esta função. Desta forma, pode-se pensar aqui que a Argumento tem o intuito de ser, através do que veicula, um meio persuasivo, que visa a mudanças de opiniões e estimula reflexões.

A ideia de fato relacionada à noção de argumento, através do slogan da revista, permite outras considerações. De maneira geral, o fato é, para Abbagnano (2007:408), "uma possibilidade objetiva de verificação, de constatação ou de controle e, portanto, também de descrição ou de previsão (...)." Esta definição leva a considerar, de certa forma, a própria Argumento como um fato, no sentido de que é algo empírico, passível de verificação. Portanto, aqui, fato e argumento se confundem. Mas, no slogan, estes termos são mediados pela palavra 'contra', em confronto: isto é, os fatos podem ser afetados ou derrotados pelos argumentos; nenhum fato fica inabalável diante de argumentos. Ou seja, através de provas, de indícios, de razões, pode-se fazer com que se admitam outras possibilidades relativas aos fatos, ou modificar, por exemplo, a forma como é visto determinado fato, o que também implica em uma negação da máxima: "Contra fato, não há argumento". Fica evidente, portanto, uma inversão de valores: demonstra-se a força de argumentos convincentes em detrimento da versão oficial dos fatos.

Para precisar melhor o sentido pode-se considerar a observação que Antonio Candido faz sobre o título da revista, afirmando que este foi utilizado com o sentido de marcar o direito da razão em funcionar contra a força. E que por isso mesmo, a decisão foi não aceitar o fato como inevitável, mas lutar na medida das forças para mudar, sugerir alternativas, abrir. A palavra argumento é tomada como sinônimo de razão, pois através desta seria possível atingir a força, que seria o fato: "Tratava-se, ante as difíceis condições do momento, de forçar quanto possível uma atitude de oposição ligada ao esforço de aprofundamento analítico" (CANDIDO, 1993, p. 97).

Não é sem propósito que Antonio Candido refere-se ao fato como força: na época, início da década de 70, os atos de repressão e censura praticados sob o comando dos militares ou os roubos e sequestros liderados pelos movimentos que aderiram à luta armada contrária ao regime são exemplos claros de violência e abusos de poder, de uma opção extremista de participar da vida cultural e política do país. Ao tomar uma posição contrária ao fato, a revista demonstra sua postura de resistência, mas é ao colocar a razão como sua opção que especifica ainda mais o seu modo de ser contra.

\section{Editorial}

Dependência, acomodação e arrivismo como formas menores de se fazer cultura, exílio de intelectuais, perplexidade, desespero e obstáculos para se publicar opiniões: é este o diagnóstico da situação do país e são estes os fatos contra os quais a Argumento se apresenta em seu editorial. Estes não são meros fatos, servem no texto como argumentos, pois são mostrados como provas a partir das quais a revista pode propor a possibilidade de existência de um outro estado das coisas. Por isso, junto a eles aparecem as propostas da publicação que dão indícios de como poderia ser esta outra situação.

A revista, primeiramente, propõe-se a preencher um "vácuo cultural" de outra forma e, procurando evitar os possíveis "obstáculos", não explicita a razão, negando apenas as formas de preenchimento que já existiam. Além disto, deseja ser um "veículo novo para o que há de vivo, válido e independente na circunstância cultural brasileira"; mais uma vez diz não à dependência e aponta para o ideal de ser "novo", "diferente", em relação ao já existente em termos de publicações sobre cultura naquele momento. Quanto a esta questão, é importante lembrar que, ao lado das publicações de vertente política que faziam resistência ao regime militar, como o Opinião, o Politika e a própria Argumento, o início dos anos 70 contou também com as publicações de vertente "existencial", ou seja, os periódicos da contracultura, que eram indiferentes ao discurso engajado, militante e buscavam novos modos de percepção, principalmente através do uso de drogas. São exemplos deste tipo de publicação a revista feminista Fotochoq e o tablóide Ex, lançados, como a Argumento, em 1973. Circulavam, portanto, ao lado de jornais e revistas da grande imprensa, como o Jornal da Tarde e Veja que, naquele momento, consolidavam seus projetos jornalísticos voltados à classe média.

Propor um esforço de lucidez parece ser a principal ideia que compõe o quarto parágrafo do editorial/ manifesto. A lucidez considerada de difícil consumo e, ao mesmo tempo, "alimento indispensável", é proposta como solução para a situação, para os fatos indicados nos parágrafos anteriores ou ainda como meio de mudança de um estado contrário ao proposto. A situação poderia ser a de um estado de alienação, de perda da razão. A alienação não proporciona perspicácia e clareza de inteligência, não permite o raciocínio, a reflexão. Neste sentido, Argumento mostra-se como um objeto esclarecedor, que anseia por 
um estado de clareza, de argúcia em meio a um estado obscuro e perturbador, o que, de certa forma, reforça a ideia de que se deseja mudar o estado das coisas através da razão.

\section{Contexto}

Vista como um segundo momento da ditadura militar instaurada em 1964, a década de 70, mostra-se, do ponto de vista cultural, muito mais tumultuada do que o período de 1964 a 1968. A política cultural em vigor desde a apresentação do Ato Institucional no 5 (19681979) manteve-se até a divulgação da Política Nacional de Cultura em 1975, durante o governo Geisel, 19741979. Esta se caracterizava, segundo Flora Süssekind (1985, p. 16-17), pela "supressão", ou seja, apreensões de livros, discos, revistas, censura rígida (como a sofrida por Argumento), demissões de professores e funcionários públicos, proibições de filmes e peças teatrais, prisões.

Porém, ao lado da repressão política e ideológica há também o estímulo à produção de bens culturais. Renato Ortiz (1995) mostra como o Estado reconhece a importância de desenvolver certas atividades na área cultural, desde que submetidas à razão do Estado, e cita uma passagem do Manual básico da Escola Superior de Guerra, que se refere aos meios de comunicação de massa como fator importante para o aprimoramento dos componentes da expressão política.

É possível, apesar do enunciado "vácuo cultural", montar um quadro de produções de alguns gêneros culturais a partir de dados da própria Argumento, o que também comprova a concretização da proposta da revista de ser um "veículo novo para o que há de vivo, válido e independente na circunstância cultural brasileira".

No teatro, verifica-se, através da revista, que enquanto em 1973 Gianfrancesco Guarnieri despontava para o sucesso, com duas peças em cartaz ("Um grito parado no ar" e "Botequim"), e o "teatro empresa", através da capitalização acelerada mediada pelo estado se consolidava (ARRABAL, 1980, p. 34), a peça "Calabaro elogio da traição", de Ruy Guerra e Chico Buarque, não tinha liberação para fazer o ensaio geral, a fim de obter o alvará para o espetáculo.

No cinema, ao lado da confirmada importância do "cinema novo" no Brasil e no exterior, a revista mostra que o cinema "atual" estava em crise. Além da burocracia pela qual tinham que passar os filmes produzidos no Brasil até chegarem às salas de cinema, o mercado era pequeno e propostas de baratear as produções e estabelecer novas vias de contato com o público eram discutidas em eventos como a $1^{\text {a }}$ Jornada Nordestina de Curta Metragem (Salvador, 1973) e o I Encontro do Cinema na Universidade, organizado por estudantes da PUC do Rio, também em 1973. Eventos estes que receberam atenção da revista.

Nas artes plásticas, em 1973, um evento artístico de grande importância foi a XII ${ }^{a}$ Bienal de São Paulo, que não recebeu muitos elogios por parte dos críticos de Argumento: Arnaldo Pedrosa D'Horta apontou problemas como a falta de critério do evento; já Marta Traba tratou da posição "inglória" que coube aos artistas latinoamericanos.

Já em relação às produções literárias do início da década de 1970, a revista não fornece dados suficientes para a montagem de um quadro geral. Por priorizar o gênero ensaístico de análise do literário, a publicação não trazia em suas páginas produções de contos, poesia ou crônicas e não chega a problematizar a produção em circulação. Observa-se apenas o destaque ao evento Expoesia I, organizado pelo Departamento de Letras e Artes da PUC do Rio de Janeiro, sob a direção de Affonso Romano de Sant'Anna, que apresentava os principais movimentos e tendências das últimas décadas (HOLANDA e BRITO, 1974).

A revista nada publicou sobre música e televisão. Ausência esta questionável uma vez que é também nesta década que ocorre a expansão da televisão e de outros meios de comunicação de massa. Em 1973, por exemplo, a Rede Globo completou a parte mais expressiva da expansão de sua rede (KEHL, 1979-1980, p. 5).

Apesar de fornecer dados e tratar de acontecimentos importantes na área cultural, a Argumento acaba por deixar de fora do cenário que arma de seu tempo alguns movimentos culturais que utilizam outras perspectivas para fazer resistência ao regime militar. São eles: o Comando de Libertação Nacional (COLINA), organizado por jovens estudantes mineiros e o Movimento Nacionalista Revolucionário (MNR) dos sargentos e marinheiros liderado por Leonel Brizola, no Rio Grande do Sul, protagonistas de lutas abertas ou clandestinas contra o regime, tinham como influência e impulso as práticas de Fidel Castro. Este "ciclo da história", como afirma Bernardo Kucinski (1991, p. 43), instituído pelo imaginário da Revolução Cubana, termina lentamente com a morte de Carlos Lamarca em 1971, com a derrota da guerrilha do Araguaia em 1972 e com a derrubada da Unidade Popular de Allende, no Chile, em 1973.

\section{Projeto cultural}

Alguns temas ecoam no periódico sugerindo certas especificidades com relação à noção de cultura da revista, como a presença recorrente do tema América Latina e a realidade do subdesenvolvimento e da dependêncida cultural. "Literatura e subdesenvolvimento", de Antonio Candido, foi publicado pela primeira vez em português 
nesta revista, figurando como o ensaio inaugural do primeiro número do periódico. Nele o autor discute como a cultura e, principalmente, as literaturas latinoamericanas ligaram-se aos grandes centros, como a Europa. Considera a dependência "derivação do atraso e da falta do desenvolvimento econômico" (CANDIDO, 1973, p. 20) e a demonstra através das fases percorridas pela literatura latino-americana até a década de 70, de forma evolutiva. O que determina tal evolução, neste caso, é o grau de consciência do atraso ou do subdesenvolvimento que assola essa parte do continente americano.

A discussão em torno das relações de dependência entre a América Latina e os países desenvolvidos e da noção de subdesenvolvimento fazem parte da perspectiva crítica de Candido, sobretudo em sua produção dos anos de 1970. Problematizada por cientistas sociais ${ }^{5}$, a teoria da dependência, como ficou conhecida, analisa em profundidade a estrutura de dominação que contém os laços da economia latino-americana com o capital estrangeiro, salientando a dinâmica interna e abordando a questão do desenvolvimento também como uma questão política. Daí sua importância no contexto de ditadura militar da América Latina dos anos 70.

Outro problema de maior interesse para Candido é o das influências literárias, considerada quase como um fato natural em decorrência de nossa origem de colonizados, mas que chegava a casos extremos de servilismo. O problema das influências, proveniente das discussões do comparatismo da época, pode também ser relacionado com a importação do romance para o Brasil. Ao considerar tal questão elemento central de sua análise, Roberto Schwarz (1974), em "Criando o romance brasileiro", lança como pressuposto de seu estudo a predominância, no Brasil do século XIX, das "ideologias de segundo grau": adotar o romance era acatar também a sua maneira de tratar as ideologias. Tais ideologias, importadas da Europa, tomavam aqui outra configuração, o que levou Schwarz a chamá-las de "ideias fora do lugar", pois aquele ideário ficava deslocado no novo contexto.

A questão do subdesenvolvimento e da dependência como tema recorrente da revista é também abordado em "Cinema: trajetória no subdesenvolvimento" (GOMES, 1973). O importante estudo de Paulo Emílio Salles Gomes acerca da história do cinema brasileiro procura discutir introdutoriamente a origem e o desenvolvimento do cinema de países subdesenvolvidos, como a Índia e a

\footnotetext{
5 O livro Dependência e subdesenvolvimento na América Latina (1967), escrito pelo sociólogo chileno Enzo Faletto em parceria com Fernando Henrique Cardoso é considerado como uma síntese e um marco da tradição dependentista. Os teóricos do dependentismo são em sua grande maioria latino-americanos, alguns oriundos da CEPAL (Comissão Econômica para a América Latina e Caribe). Fernando Henrique Cardoso, um dos colaboradores de Argumento, encontra-se exilado no Chile naquele momento.
}

Arábia, ou ainda com o desenvolvido Japão. Propondo um desenrolar de texto que mostra, da mesma forma que o artigo de Antonio Candido, uma evolução, Paulo Emílio trata do meio cinematográfico brasileiro baseando-se nas fases de maior expressão e em seus intervalos.

Neste sentido ainda, os autores, através do que apresentam como superação da situação de subdesenvolvimento ou maturidade na área cultural brasileira, demonstram também um ideal de cultura vinculado à expressão do subdesenvolvimento e da identidade brasileira. Apontando a saída da dependência e do subdesenvolvimento cultural, ora pela busca de uma fonte de criação também nacional, ora fazendo com que as produções culturais apresentem a consciência do que é de fato o país, a revista Argumento prima por uma cultura que valorize o nacional pelo que historicamente ele é: dependente e subdesenvolvido. Esta consideração, que está também na base do desenvolvimento visado pela "teoria da dependência" (CARDOSO e FALETTO, 1970, p. 10), levaria o Brasil, ou melhor, a América Latina a ter um lugar de destaque junto ao contexto mundial. Apresenta-se também como a afirmação de uma identidade nacional e de uma cultura brasileira.

Por outro lado, a demonstração da evolução pela qual passa a literatura latino-americana dá a ideia de um certo "progresso" no meio literário, que decorreu do afinamento das potencialidades dos escritores latino-americanos e que poderia se firmar futuramente. Essa crença no futuro que, no caso, está próximo, pois Antonio Candido já aponta para uma "nova literatura" (o super-regionalismo) que está surgindo, remete à ideologia iluminista que via a América Latina como um "continente novo", um "gigante adormecido", destinado a ser grandioso. Além disso, a indicação de Schwarz sobre a possibilidade de existência de um "romance verdadeiro" aponta para a crença em uma verdade, ou seja, um ideal de romance. Persiste, na revista, portanto, a presença, já diagnosticada na leitura do título e do slogan, de ideais iluministas, como o apoio na razão.

\section{Identidade nacional}

A noção de "consciência" é um dos pilares do artigo de Antonio Candido, como se ressaltou anteriormente. De acordo com o grau de consciência da realidade da América Latina é que a literatura se apresenta mais ou menos dependente. Ao qualificar o Cinema Novo como um dos melhores momentos do cinema brasileiro, Paulo Emílio está defendendo um processo de conscientização a que visa este tipo de cinema. Sendo assim, a "consciência" ou a "falta de consciência" que se vincula à situação de subdesenvolvimento do continente latino-americano também é central em Argumento. Noutras palavras, ao 
que tudo indica, a revista constrói uma ideia de povo brasileiro e latino-americano a partir de sua explicação acerca da situação de subdesenvolvimento da região, o que implica uma cultura alienada, ou seja, o latinoamericano tinha uma consciência pouco apurada da realidade em que vivia.

Tal consideração evoca uma luta contra a "consciência alienada" ou contra a "falsa consciência" das elites europeizadas, não há mais "ufanismos" nacionalistas próprios, talvez, de uma consciência amena do atraso e é neste sentido que também se pode pensar na defesa de uma "cultura desalienada" e a construção de uma identidade, no periódico, que se contraponha ao estrangeiro. Portanto, a superação do subdesenvolvimento cultural pressupõe estímulos a movimentos culturais internos, desenvolvendo, assim, uma cultura própria, mesmo que inserida num universo cultural, pois, como afirmou Candido, "somos parte de uma cultura mais ampla, da qual participamos como variedade cultural" (CANDIDO, 1973, p. 18), só que não mais numa situação de dependência.

É importante lembrar que esta busca de uma cultura essencialmente brasileira já se encontrava no movimento modernista. As noções de consciência e alienação e os ideais citados foram também preocupações recorrentes nas reflexões dos intelectuais do ISEB (Instituto Superior de Ensino Brasileiro) nos anos 50 e início dos $60^{6}$, de que faziam parte Celso Furtado e Hélio Jaguaribe, ambos colaboradores de Argumento. Antes, porém, de serem aproveitados por estes intelectuais, os conceitos de alienação e consciência foram elaborações-chave da teoria marxista, que os utilizava para desvendar o sistema capitalista, na tentativa de subvertê-lo.

Para Antonio Candido (1973, p. 18), "quanto mais se imbui da realidade trágica do subdesenvolvimento, mais o homem livre que pensa, se imbui da inspiração revolucionária". E esta consciência crítica, mas principalmente, o ideal de fazer com que surjam mais consciências críticas, está também no Cinema Novo. Assim, pode-se afirmar que, ao se combater a alienação, está se defendendo uma conscientização ou uma desalienação. Nestes termos também é que pode ser pensada a construção da ideia de cultura e identidade nacional em Argumento.

\section{Discurso de resistência}

A revista Argumento resiste ao que está político e culturalmente instituído, ou seja, ao que o governo militar e o sistema capitalista impõem, da mesma forma que é contrária a outros modos de se fazer resistência (uso da força e das armas), assumindo-se um periódico que opta pelo raciocínio e a reflexão analítica e científica, isto é, que não se baseia apenas em opiniões.
Então, se a conscientização da realidade do subdesenvolvimento, conforme Antonio Candido, leva o "homem livre que pensa" a resistir a esta realidade, poder-se-ia afirmar que Argumento se posiciona a favor de uma cultura de resistência, buscando contribuir para este processo de conscientização através das críticas à realidade latino-americana marcada pelo estado de subdesenvolvimento e dependência e pelo autoritarismo dos governos militares, presentes em várias partes deste continente.

Se a "inspiração revolucionária" é "o desejo de rejeitar o jugo econômico e político do imperialismo e de promover a modificação das estruturas internas, que alimentam a situação de subdesenvolvimento" (CANDIDO, 1973, p. 18), a Argumento também está imbuída deste ideal. O espaço dado ao modernismo de 30 , marcado pela crítica da realidade brasileira, une-se às críticas sutilmente lançadas à ditadura militar presente em vários de seus artigos: no informe que denunciava o fechamento, pela censura, da revista peruana Politica y Sociedad; no ensaio de Fernando Henrique Cardoso $(1973)^{7}$ sobre a situação política chilena pouco antes da derrubada de Allende; ou ainda na constante crítica à censura que circundava as produções culturais da época, presente em vários artigos, tais como: a entrevista feita com Gianfrancesco Guarnieri (Argumento, n. 1); o informe de Sérgio Santeiro, "O direito de nascer do cinema brasileiro" (Argumento, n. 4), que comenta a não concessão do "certificado de filme brasileiro" a alguns filmes nacionais (que permitiria a exibição do filme em casas cinematográficas); o texto "Histórico de um aborto" de Fernando Peixoto (Argumento n. 4), que trata da peça teatral "Calabar, o elogio da traição", censurada.

Assim sendo, pode-se afirmar, a partir daqui, que a revista Argumento privilegiou artigos que apontavam para certo comprometimento político, que tomavam posição diante das questões e que representavam, em certa medida, alguns dos ideais do pensamento de "esquerda" que fazia parte da cena brasileira dos anos 70. A cultura valorizada pela publicação era também uma cultura comprometida politicamente, uma cultura de resistência, porém, de uma resistência que tinha um modo próprio de se expressar. Como se viu, ser contra, a partir do slogan da revista, indica utilizar a inteligência e o raciocínio, a razão e/ou a argumentação para se opor à força.

\footnotetext{
6 O ISEB teve suas atividades encerradas com o golpe militar de 1964. Renato Ortiz, em Cultura brasileira e identidade nacional (1991), mostra como os ideais dos intelectuais do ISEB se transfiguram até chegarem, no início dos anos 60, através do Centro Popular de Cultura da UNE, em uma noção de "cultura popular" que tem como base a ideia de uma ação de caráter reformista, transformadora.

7 É válido anotar que Fernando Henrique Cardoso tornou-se presidente do Brasil, pelo PSDB, governando por dois mandatos consecutivos, entre 1995 e 2002. No entanto, esteve à frente de uma política neoliberal, cujas marcas foram grandes processos de privatizações de bens públicos.
} 
Dentro desta discussão em torno a cultura de resistência, encontra-se o papel dos intelectuais. Em "O contexto e os intelectuais", artigo do último número de Argumento, José Arthur Giannotti tem como objetivo analisar a forma pela qual o produto do trabalho intelectual se insere no sistema produtivo da época. No que se refere à função dos intelectuais, afirma que:

Se a hora é de tomada de consciência, cabe tomá-la a partir da situação peculiar em que nos encontramos, notadamente de nossas próprias condições de trabalho. Isto para evitar a consciência simplesmente moral que contraponha o bem ao mal, sem se deter nos processos concretos de mudança. A todo momento nossa atividade esbarra com a sólida presença do Estado, instituição todo-poderosa que nos fascina e atomiza. Não é nossa a posição daqueles grupos que lutam para serem cooptados por ele. Preferimos aceitar nossa marginalidade de intelectuais e aprofundar nossa atividade e descobrir nela sua dimensão social, para organizá-la a partir de bases efetivas (GIANOTTI, 1974, p. 58).

A "tomada de consciência" é retomada aqui em relação ao intelectual, ou seja, para Giannotti é hora de os intelectuais se conscientizarem quanto à situação do país, promovendo um trabalho de oposição, de crítica e de não cooptação. Além disso, o autor afirma que o trabalho intelectual, na situação colocada, era marginalizado, tinha-se apenas um pequeno espaço onde ele poderia ser exercido efetivamente, tudo isto em decorrência do amplo poder do Estado.

O intelectual, nesta publicação, assemelha-se, em alguns aspectos, e distingue-se em outros, das noções de intelectual que circulavam no período. Uma dessas noções é a elaborada a partir da prática do Centro Popular de Cultura (CPC) da UNE (1962-1964): o CPC produzia e organizava eventos artísticos, principalmente teatrais, que visavam motivar, predispor, criar atitudes favoráveis à participação política do povo da mais baixa camada social. Assim, mais importante do que a parte artística era o conteúdo e a forma enquanto comunicação com o público, mostrando que é intelectual quem leva a cultura às massas e quem pode politizá-las (Cf. MARTINS, 1980). O CPC falava sobre o povo e para o povo, mas sempre dentro de uma perspectiva de cima para baixo, ou, como ressalta Renato Ortiz (1991, p. 73), de exterioridade. No caso dos intelectuais da Argumento, percebe-se também uma exterioridade ainda maior em relação à massa, como se os intelectuais fossem uma classe, entre outras. Neste sentido, afasta-se da noção de "intelectual orgânico" de Gramsci, o qual vê tal categoria vinculada aos interesses populares e deles emergindo; assim, cada grupo social tem seu intelectual (Cf. GRAMSCI, 1991). A revista trata também do povo, mas não se dirige a ele, nem mesmo o faz falar, criando, por exemplo, uma performance do povo. É aos próprios intelectuais e estudantes das universidades que a Argumento se dirige, eis o público da publicação.

Enfim, torna-se imprescindível afirmar que a revista Argumento não só se contrapunha à realidade social e política, mas também ao projeto cultural do Estado. Diga-se de passagem, o Estado, para desenvolver seu projeto cultural, voltou-se para os intelectuais que se colocavam a favor do golpe militar e, como afirma Renato Ortiz (1991:91), tais intelectuais eram membros de um grupo caracterizado como tradicionais. De forma alguma representavam os interesses dos intelectuais e produtores culturais que vinham atuando antes do golpe. No mesmo sentido, Roberto Schwarz diz que:

\begin{abstract}
(...) no conjunto de seus efeitos secundários, o golpe apresentou-se como uma gigantesca volta do que a modernização havia relegado; a revanche da província, dos pequenos proprietários, dos ratos de missa, das pudibundas, dos bacharéis em lei etc. Para conceber o tamanho desta regressão, lembre-se que no tempo de Goulart o debate público estivera centrado em reforma agrária, imperialismo, salário mínimo ou voto do analfabeto, (...). Depois de 64 o quadro é outro. Ressurgem as velhas fórmulas rituais, anteriores ao populismo (...): a célula da nação é a família, o Brasil é altivo, nossas tradições cristãs, frases que não mais refletem realidade alguma, embora sirvam de passepartout para a afetividade e de caução policialideológica a quem fala (SCHWARZ, 1978, p. 71).
\end{abstract}

Esta ideia de "regressão" está também nas reflexões de Ortiz sobre o Conselho Federal de Cultura (CFC), criado em 1966, cujo objetivo era coordenar as atividades culturais da época. O Conselho, quando considera que a cultura brasileira é plural e variada, procura enfatizar o aspecto da diversidade e retoma, de certa forma, as ideias de Gilberto Freyre (intelectual tradicional), dentre as quais o conceito de pluralidade, que encobre uma ideologia de harmonia: "diversidade significa unicamente diferenciação, o que elimina a priori os aspectos de antagonismos e de conflito da sociedade" (ORTIZ, 1991, p. 94).

\section{América Latina}

Uma das propostas da revista Argumento, presente no editorial do primeiro número, é a de ser "um ponto de encontro com o pensamento de outras terras, notadamente as do continente". À proposta une-se um depoimento de Antonio Candido que, alguns anos depois do encerramento do periódico, confirmou o propósito de tornar a revista uma "publicação de cunho e âmbito latino-americanos" (CANDIDO, 1993, p. 263). 
Ao preocupar-se com a situação latino-americana, a Argumento não quer apenas garantir a presença desta discussão em suas páginas, mas principalmente visa reforçar sua posição a favor da democracia e da superação do subdesenvolvimento e contrária à irracionalidade das forças ditatoriais ou de direita, retomando, desta forma, a leitura feita de seu slogan - "Contra fato, há argumento". Mesmo quando trata da literatura latino-americana, a revista não descarta seu posicionamento, antes reafirma-o.

Para Ángel Rama e, da mesma forma, para César Fernández Moreno, que na mesma época, na introdução ao livro América Latina em sua literatura (1979), reflete também sobre as várias designações que recebeu o continente, mostrando seus problemas, chamar esta região de América Latina é expressar uma unidade. Já os termos "Ibero-américa" ou "Hispano-américa" não seriam apropriados, pois o primeiro excluiria os descendentes da colonização francesa, como o Haiti, e o segundo se reduziria apenas aos países de língua espanhola. O termo América Latina também envolve exclusões: a palavra "Latina", nesse conceito, implica, como sublinhou Moreno (1979, p. XV-XVIII), considerar somente a influência dos colonizadores do continente, o que leva a descartar a presença não-latina do africano e dos indígenas que também povoaram esta região.

A opção por América Latina, para estes críticos, ocorre devido à grande aceitação e disseminação que a expressão obteve, tornando-se comum em toda parte e em vários âmbitos. Mas, ao projetar uma historiografia literária latino-americana unificadora da produção literária do continente, Ángel Rama definia ou estabelecia critérios para o que se poderia considerar latino-americano. Considerava a compreensão do campo cultural como base unificadora. Esta compreensão ou, como chama Rama, "solução crítica", é atribuída, pelo crítico, a Pedro Henríquez Ureña, que foi quem conseguiu a primeira integração das literaturas de língua espanhola e portuguesa numa obra. Para Rama:

\begin{abstract}
Só seria possível reintegrar num mesmo discurso duas línguas em função literária, na medida em que se pudesse estabelecer uma correlação cultural, que abre de imediato a porta para correlações infraestruturais, onde se nutrem, como linhas culturais paralelas, a literatura, as artes plásticas, a arquitetura, a música, etc. (RAMA, 1974, p. 42).
\end{abstract}

A partir de então, Rama expõe três traços definidores do comportamento cultural desta região que irão servir de justificativa para a integração projetada por ele e que, de certa forma, servem também como compreensão do que Rama entende por América Latina, ou pela cultura latinoamericana. Os três traços seriam: "ampliação lógica do princípio de correlação cultural”, isto é, uma identidade comum enformada pela herança românica; "forma de apropriação das culturas estrangeiras (românicas ou não), própria de um continente dotado de estrutura econômica dependente" e "a estrutura cultural da América Latina tanto no que se refere ao seu mestiçamento (...), quanto à peculiar estratificação social do continente ao longo dos séculos (...)" (RAMA, 1974, p. 46-47). Assim se constitui, portanto, a base do projeto de integração visado por Rama.

Observa-se que, em Argumento, a integração se dá também devido a estes critérios, mas especialmente pelo aspecto básico desta integração, a cultura. É a partir da cultura, haja vista ser uma publicação cultural, que a revista vai tratar da América Latina e essa cultura constitui-se, já se apontou, como cultura de resistência, que se opõe à situação de subdesenvolvimento e à falta de consciência, à cultura alienada e massificada e à irracionalidade de algumas formas de poder.

Ángel Rama não só defendia a ideia de que os intelectuais latino-americanos deveriam se preocupar em conhecer, contatar e fazer intercâmbios com os países da América Latina, como afirmou Antonio Candido (1993, p. 263) em um texto em sua homenagem, como inclusive se prontificou a começar este trabalho. Um de seus artigos do final da década de 70, intitulado "Programa de estúdios latinoamericanos" (1976), menciona o programa que estava sendo proposto à Universidade de Caracas, que tinha em vista a criação de um Centro de Estudos Latino-Americanos. O programa não só incentivava o conhecimento da América Latina através da inserção de cursos nas universidades e criação de centros de estudos com intuito deste conhecimento, como esboçava a origem deste movimento integrador. Outras atividades de cunho integracionista terão lugar nas décadas seguintes, basta ver as Jornadas de Literatura latino-americana realizadas em Campinas, na década de 1980 e os encontros e reuniões para a constituição da história da literatura latinoamericana, dirigida por Ana Pizarro, que tiveram como resultado a publicação, na década de 1990, de 3 volumes intitulados: América Latina: palavra, literatura, cultura.

Esta "vocação integradora", como chama Rama, que tem origem no pensamento de Simon Bolívar (17831830), é baseada na solidariedade entre os povos e homens que são considerados iguais e com os mesmos direitos (Cf. ZEA, 1976). Neste sentido, Bolívar afirmou: "Yo deseo más que otro alguno ver formarse la más grande nación del mundo, menos por su extensión y riqueza que por su libertad y gloria" (apud ZEA, 1976, p. 37). Deste modo, Bolívar acentuava a diferença entre uma união de países com finalidade de enriquecimento e poder sobre os demais, como as sociedades modernas, e uma união com o objetivo de integração de junção de forças para chegar a metas comuns através de sua própria independência, com liberdade e glória. 
Este ideal de integração tornou-se um elemento caracterizador da América Latina. Voltou-se sempre a ele, em épocas específicas da história deste continente. Afirma Rama:

En muchos momentos aciagos de la historia de América Latina, cuando se sucedieron las intervenciones de los imperios extranjeros, esta gran tradición fue un útil instrumento de afirmación independiente y soberana, de lucha contra las intromisiones foráneas y de resguardo de la especificidad cultural latinoamericana (RAMA, 1978, p. 73).

Portanto, o ideal de integração, mesmo sendo um projeto, manteve-se vivo, tornando possíveis relações, de cunho econômico, por exemplo, entre os países desta região. Quanto às intervenções estrangeiras a que se refere Rama, o momento no qual está inserida a revista Argumento, que traz consigo também este ideal de integração, é o mais propício, pois vários países da América Latina sofriam, na mesma época, com as ditaduras militares que, nas breves palavras de Roberto Schwarz (1978, p. 61), tinham o objetivo de "garantir o capital e o continente contra o socialismo". Como se pode observar nos artigos de cunho político citados anteriormente, alguns países da América Latina passavam por um momento, em alguns casos, de grande efervescência (Chile, Argentina, Venezuela), e em outros, de repressão política (Brasil), tendo como elemento fundamental a interferência externa, notadamente a norte-americana. O ideal de integração, desse modo, servia como uma forma de resistir ao autoritário regime militar, pois tinha em sua base o discurso de solidariedade entre os povos e o de construção de uma ideia de nação.

\section{Últimas considerações}

A produção de revistas literárias e culturais em nosso país sempre agitaram e fomentaram os estudos de literatura. Algumas publicações marcaram época e constituíram momentos importantes da nossa história literária. São aquilo que Josefina Ludmer (2002) chama de "formações culturais" pois, compreendem práticas e noções culturais atuantes em um momento. Desta forma, não há como não considerá-las como pertencentes a um campo mais amplo, o da história literária e cultural. Sua relação com o campo cultural é definida pelas implicações a que estão sujeitas sua enunciação.

Quem escreve, sobre o que se escreve, de onde se escreve, questões perseguidas neste estudo da revista Argumento, constituem o discurso do periódico. Como nos ensinou Michel Foucault (2010), o discurso não é um encadeamento lógico de palavras e frases que visam a um significado em si mesmo, ainda que essa estratégia seja empregada, e sim uma importante organização funcional onde se estrutura um imaginário social. Ao demarcar seu projeto cultural e, com ele, seu imaginário, Argumento colocou em evidência a existência de diferentes discursos e práticas no contexto em que circulava. Em um momento de liberdade cerceada, os princípios presentes no discurso deste periódico, sejam eles éticos, políticos ou estéticos, foram fatais para sua existência. No entanto, ainda que não tenha alcançado longo tempo de duração, a revista destacou-se pela contribuição ao fortalecimento de um discurso social e político que também constitui a história literária e cultural do continente.

\section{Referências}

ABBAGnANO, Nicola. Dicionário de filosofia. Trad. Alfredo Bosi. São Paulo: Martins Fontes, 2007.

ARRABAL, José. Anos 70: momentos decisivos da arrancada. In: Série anos 70 - teatro. Rio de Janeiro: Europa, 19791980.

CANDIDO, Antonio. Literatura e subdesenvolvimento. Argumento (Rio de Janeiro: Paz e Terra), n. 1, p. 6-24, out. 1973.

CANDIDO, Antonio. Uma visão latino-americana. In: CHIAPPINI, Ligia; AGUIAR, Flavio (Orgs.). Literatura e história na América Latina. São Paulo: EDUSP, 1993.

CANDIDO, Antonio. O gosto pela independência. In: Recortes. São Paulo: Companhia das Letras, 1993.

CARDOSO, Fernando Henrique; FALETTO, Enzo. Dependência e desenvolvimento na América Latina: ensaio de interpretação sociológica. Rio de Janeiro: Guanabara, 1970.

CARDOSO, Fernando Henrique. Chile: um caminho possível. Argumento, n. 1, p. 95-103, out. 1973.

FOUCAULT, Michel. A ordem do discurso. 18. ed. São Paulo: Loyola, 2010.

GIANNOTTI, José Arthur. O contexto e os intelectuais. Argumento, n. 4, fev. 1974.

GRAMSCI, Antonio. A formação dos intelectuais. In: Os intelectuais e a organização da cultura. 8. ed. Rio de Janeiro: Civilização Brasileira, 1991. p. 3-23.

GOMES, Paulo Emilio Salles. Cinema: trajetória no subdesenvolvimento. Argumento, n. 1, p. 54-67, out. 1973.

HOLANDA, Heloisa Buarque de; BRITO, Antonio Carlos de. Nosso verso de pé quebrado. Argumento, n. 3, p. 81-94, jan. 1974.

HOLANDA, Heloisa Buarque de; GONÇALVES, Manoel Antonio. Política e literatura: a ficção da realidade brasileira. In: Anos 70 - literatura. Rio de Janeiro: Europa, 1979-1980. p. $7-82$

KEHL, Maria Rita. Um só povo, uma só cabeça, uma só nação. In: Anos 70 - televisão. Rio de Janeiro: Europa, 1979-1980. p. 5-30.

KUCINSKI, Bernardo. Jornalistas e revolucionários: nos tempos da imprensa alternativa. São Paulo: Página Aberta, 1991. 
LUDMER, Josefina. Temporalidades do presente. Margens, margenes (Belo Horizonte), n. 2, p. 14-27, dez. 2002.

MARTINS, Carlos Estevam. História do CPC: depoimento de Carlos Estevam Martins. Arte em revista (São Paulo: Kairós), n. 3, p. 77- 82, mar. 1980.

MORENO, César Fernández. América Latina em sua literatura. São Paulo: Perspectiva, 1979.

ORTIZ, Renato. A moderna tradição brasileira. São Paulo: Brasiliense, 1995.

RAMA, Ángel. Um processo autonômico: das literaturas nacionais a literatura latino-americana. Argumento, n. 3, p. 36-49, jan. 1974.

RAMA, Ángel. Programa de estúdios latinoamericanos. Almanaque, cadernos de literatura e ensaio, n. 11. São Paulo: Brasiliense, 1976.
SCHWARZ, Roberto. Criando o romance brasileiro. Argumento, n. 4, p. 19-47, fev. 1974.

SCHWARZ, Roberto. Cultura e política, 1964-1969. In: SCHWARZ, R. O pai de família e outros estudos. Rio de Janeiro: Paz e Terra, 1978.

SÜSSEKIND, Flora. Censura: uma pista dupla. In: Literatura e vida literária: polêmicas, diários \& retratos. Rio de Janeiro: Jorge Zahar, 1985.

ZEA, Leopoldo. Dialética del pensamiento latinoamericano. In: El pensamiento latinoamericano. Barcelona: Ed. Ariel, 1976. p. 36-41.

Recebido: 27 de abril de 2014

Aprovado: 05 de junho de 2014

Contato: deboracota.lit@gmail.com 